\title{
Glass-buildings - how lay people and professionals communicate about them ${ }^{3}$
}

\section{Abstract}

In the present study we introduce the Grounded Theory method through the example of a study about similarities and differences in the opinions regarding glass façade buildings. We highlight the importance of using different samples. From a methodological point of view it is of utmost importance to pick the right method for data collection. Glass façade buildings have special psychological meanings which are different for lay people and professionals. In the study used as an example the sources of information were lay people and professional and lay media outlets. Qualitative content analysis was used to explore these parities and divergences. We introduce the capabilities and shortcomings of the Grounded Theory method we encountered during our research.

Keywords: glass façade, lay people and professionals, media content analysis, environmental psychology, methodology

\section{Introduction}

This study focuses on the methodological questions: how opininons, attitudes can be explored and what difficulties emerge on the way. One of the qualitative research methods, qualitative content analysis, more specifically the Grounded Theory method is

1 Assistant lecturer, Budapest Business School Faculty of Commerce Hospitality and Tourism, Department of Pedagogy; PhDstudent, ELTE Eötvös Loránd University, Doctoral School of Psychology: e-mail: keszei. barbara@uni-bge.hu.

2 DSc PhD, professor, ELTE Eötvös Loránd University Institute of Psychology; professor, Budapest University of Technology and Economics, Department of Sociology and Communication; e-mail: dandi@caesar.elte.hu.

3 This work was completed in the ELTE Institutional Excellence Program (783-3/2018/FEKUTSRAT) supported by the Hungarian Ministry of Human Capacities for Andrea Dúll.

DOI: http://dx.doi.org/10.31570/Prosp 2019016. 
introduced. To better understand the method itself the example from the field of environmental psychology is used. Our research aims to explore and compare the opinions - deriving from three different sources - about glass façade buildings.

This is important because when examining opinions about a certain topic it is essential to be very conscious about the sampling process and the way of choosing the data collection method. Often times opininons from sources of opposing interests can prove to be on opposite ends of the same spectrum, which makes awareness about the sources themselves extremely important (e. g. corrupt governments vs. watchdog organisations). Methodological decisions such as choosing the sample are guided by the research topic, but they are narrowed down further when arriving at research questions or hypotheses. In the present study people's opinions about glass façade buildings are used as an example to gain insight as to the different methods of data collection and sampling when examining opinions about built environments.

This study was chosen for demonstrating the capabilities of Grounded Theory because (1) not much is known about differing opinions regarding glass façades; (2) the effect architecture has on everyday life is without doubt significant, however underresearched. For this exploration the best method is qualitative content analysis (Babbie 2015).

\section{Importance of architecture in society}

Built environments always reflect the sociological, economical, technical and cultural values of a given era (Nagy 2005). Architecture is one of the most ancient and still one of the most efficent and powerful forms of mass-communication, arguably the most visible form of manifested values. Architecture is present in our everyday lives and it provokes emotions on a personal level, on social goups' level, and also on the level of society (Sudjic 2006). Therefore examining architecture, and connotations of architecture is important especially in social sciences.

Some architects have thought the connection between architecture and society mentioned above is so straightforward that architects determine how people behave in a given environment, that is, how a society functions. Architectural determinism as an idea is most prevalent in the work of architects of the modern, such as Le Corbusier and Bruno Taut. Modernist architects believed that with the creation of transparent built environments social, political problems would also become transparent and thus easily solved (Bonta 1995). The death of the idea of architectural determinism was provided by the demolition of the Pruitt-Igoe Social Housing Project in Saint Louis. The 
buildings were inspired by modernist ideas and were built in 1954-56, but 18 years after their unveiling circumstances in the housing project became unbearable that led to its demolition in 1972. This marked the end of an era. Postmodern architecture and architects did not want or believe that they could make or break our lives (Sudjic 2006).

Architecture is often used by power figures as a tool of self-definition (Bataille 1929, idézi Crinson 2012; Sudjic 2006). This is also the reason why when thinking about a certain architectural style we immediately associate it with a certain political era or party, even though these associations can be very misleading (e. g. social-realism in architecture). Power figures need architects who are appreciated and legitimized by the general public and architects need powerful people and institutions to fund their projects. Therefore the relationship between architects and investors (with political or business backgrounds) will have an effect on the building regarding its function, design concept, sometimes details and obviously its realization (Sudjic 2006).

A threefold communication among architects, the general public and investors would be essential to create user friendly, likeable buildings. The lack of communication and proper media coverage of architecture and architects (not to mention investors) can render the opinions of the above mentioned participants disparate. The unknown stylistic language of contemporary architecture itself can cause negative emotions and attitudes toward the buildings representing it. When the architectural style referred to as 'modern' was introduced to the public, architects had to face the negative emotions mentioned above from the general public and only a few groups understood and resonated with the style and the ideas behind it (Bonta 1995). Knowing or being familiar with an idea, a person, a group, an advertisement, a city, a tradition, a building, the style of a building, etc. creates a positive attitude towards the given subject. The unknown - on the other hand - often causes negative emotions (e. g. Smith-Mackie 2004; Dasgupta et al. 2009), even fear (Carleton 2016).

Communication about the physical environment is not an easy task even by appending visual content about the building. To truly understand these visual tools and the building itself, one either needs training, practice - or a very good skillset - in a spatiovisual field. These visual tools (photos, layouts, sections, etc.) mostly help professionals to understand a certain place (Bun 2006). Another issue with photos used in the media is that sometimes these images are aiming to be artworks themselfes, therefore being aesthetically pleasing but not necessary conveying information about the building itself (Cseri 1998; Gyáni 2005; Somogyi 2015), and these pictures might be misleading about the true quality or aesthetics of the given building. 
Communication about architecture and physical environments in general suffers from specific terms not being easy to understand - or outright unintelligible - for lay people. To further broaden the gap some terms have different meanings for the general public and for professionals (e. g. Gifford et al. 2002). The two groups use different coding systems to formulate and create aesthetic judgments. This communicational situation can be seen as a sort of prisoner's dilemma situation (Kreps et al. 1982), as one group should co-operate and acquire this code system to initiate meaningful communication and create a viable and aesthetically pleasing environment.

\section{Connotations in architecture}

When arriving in a new environment, a new location, people immediately have opinions, attitudes, make judgments about it, thus it instantly acquires a psychological meaning. Physical characteristics of the environment play an important role in creating this meaning. The meaning itself can vary among and even within people, but it definitely exists in both a conscious and a non-conscious form (Batár 2005). Interpreting architectural signs and meanings is an extremely difficult task and can cause many misunderstandings. A very prevalent example of how the supposedly clear message could get misinterpreted is the example of the new Reichstag dome by Norman Foster in Berlin.

The Reichstag's new glass dome was supposed to symbolize the openness and transparency of democracy, according to official political beliefs and the architect's ideas. One of the problems that appeared in the media criticism of the glass dome is that 'non-transparent' affairs can be done in a transparent building just as well, not exclusively in one with thick, opaque walls. It is easy to abuse, misuse or ignore the message conveyed by the architectural style even in the case of straightforward, clear messages. Hans Idann, former chief architect of Berlin, summed up this idea as follows: 'Democracy lives in the brain, it has nothing to do with glass' (Szépvölgyi 2007: 23).

Another problem is the true content and clarity of the message. The building should symbolize democracy, but the process of meaning-making is not as clear-cut and easy as the straight association between 'transparent walls' and 'transparent political system'. The meaning is defined in several layers by subjective, non-conscious, symbolic meanings, which are completely opposed to a transparent and rational meaning-making process (Donald 1999, idézi Deriu 2001). Of course, there are architectural elements and gestures that cannot be questioned (Sudjic 2006), but the architectural form language is not always suitable for delivering more subtle political messages (Jarosinski 
2002). Due to complex processes, the intended meaning may be mistaken and lead to different interpretations (Sudjic 2006).

A further problem with interpretation is time. Although buildings can survive for decades or millennia, their political role and meaning have the most importance at the time of their creation. With time passing by certain buildings, environments can obtain different meanings. Turning back to the example of the Reichstag, the building was a symbol of the defeat of Nazi Germany, despite the fact that it did not play any role in Hitler's regime. Hiring a British architect and creating a transparent building clearly had a political meaning on several levels (Sudjic 2006), but it is doubtful how much of these layers of meaning can or will be decoded by the present day users of the building.

\section{Differences between lay people and architects}

Communicating and conciliating professional and lay opinions and approaching an in-depth understanding of opinions can be an important tool in designing and building physical environments (such as streets, public spaces, schools, hospitals, offices, etc.) liked by both architects and users (e. g. Martin et al. 2007; Fawcett et al. 2008). The question arises whether architects know what laymen think, are the same concepts and evaluation systems used by architects and non-architects. Do architects disagree with lay people or do they misunderstand each other?

Professionals accurately predict that lay people generally evaluate buildings more positively, but they cannot specify the reasons for this phenomenon. Experts and laymen agree that a 'good' building is meaningful, friendly, uneven and original. However, they do not agree on which buildings represent these key variables. Studies show that architects used materials as a decisive physical stimulus (for example, the façade was metal, brick or stone), while laymen relied more on shapes in their judgments (roundness, ornamentation, etc.). (Brown-Gifford 2001) Several studies (e. g. Kaplan 1973, idézi Dúll-Urbán 1997) confirmed that architects stress certain characteristics (such as coherence) more in their preferences than laymen.

Most studies found differences between professionals and lay people when using a semantic differential scale (e. g. Brózik 2006; Brown-Gifford 2001; Gifford et al. 2002; Kaplan 1973, idézi Dúll-Urbán 1997). The exceptions either used a city scale environment (Gjerde 2011) versus the building scale in other studies, or did not differentiate between freshmen and senior architect students, and referred to them together as professionals (Hidayetoglu et al. 2010). In summary, when forming judgements about environments and using categories describing environments, architects use more com- 
plex features (e. g. architectural value, style, historical significance) and relationships during the process. At the same time laymen use, as stated above, simpler features (e. g. shape of the roof) when shaping their preferences.

In order to resolve the contradiction between the two groups, it is worth looking for answers in personal experience: in the course of professional training, architecture students acquire a special rating system, code system that influences what kind of buildings they should like and why. Lay people without said training have different categories to describe a building, to consider a building beautiful or not, to prefer it or not (e. g. Brown-Gifford 2001; Gifford et al. 2002; Brózik 2006; Hidayetoglu et al. 2010; Dúll 2017). These different categories can also be manifested in the media.

\section{Intorduction to qualitative research methods}

\section{Qualitative research in general}

In order to better understand the method of Grounded Theory, we must review the general features of qualitative methods in content analysis that are also true for the Grounded Theory. Qualitative methodology is an inductive research strategy and has a holistic, subjective approach towards understanding a given phenomenon. It perceives reality as a social construct and seeks a 'dense' description of it embedded in the context.

Research starts with open questions, or if there are any hypotheses, they are broader and less specific. The focus is on exploring and presenting phenomena. Issues that arise 'on the go' are not treated as a problem but are relied upon, and are an important part of deepening our knowledge about the given topic. Qualitative research methods are characterized by shaping and changing during the research process with the gradual formation of both the research question and the hypothesis (Szokolszky 2004).

Research conducted this way uses simple measurements and smaller sample size or even individual cases, mainly focusing on exploring the topic instead of statistical analysis and measurability. Although the sample size is usually smaller than in the case of quantitative research, the time involved in data collection is longer, as research is influenced by the issues that arise during the research itself and by the thorough examination of the context (Szokolszky 2004).

The style of the publication presenting the above mentioned research might be more personal, with a less rigid structure. Its conclusions can even be narrative descriptions or interpretations, unlike those in quantitative studies (Szabolcs 2001; Szokolszky 2004). Qualitative and quantitative methodologies might seem to have different ap- 
proaches but it is worth noting that combining these methods can strengthen a research, using the advantages of each of the strategies while implementing an integrated research methodology model (Sántha 2009).

\section{Grounded Theory}

A common theoretical model for qualitative research is the so-called Grounded Theory method (GT) (Glaser-Strauss 1967; Corbin-Strauss 2015). In fact, this model provides a framework for the researcherss to work in while structuring their thoughts regarding the given research topic, also providing great freedom for creating theories and models to describe the given phenomena. This model grants an opportunity for researchers to be scientific and creative at the same time (Babbie 2015).

The method entails three phases (Szokolszky 2004): (1) In parallel with data collection starts the development of research categories. These categories should help to organize data and illuminate its essence. (2) Data collection, shaping and developing the category system continues until the 'saturation', that is until new issues arise and the system is consistent with the data. (3) The created categories are incorporated into a more general theoretical system and are extended to other contexts.

During the process of data analysis the researchers have to take a step back from time to time and ask critical questions about the analysis itself (e. g. are the categories in formation consistent with the data; are there any 'personal' favorites), these questions help to preserve skepticism about findings, which is essential in all types of research. Documenting the analysis is important to keep the interpretations of the research easy to follow, and somewhat controlled to retain objectivity and to helpresults represent reality (Babbie 2015). The sample for grounded theory can derive from a lot of sources: transcriptions of interviews, text of open-ended questions, media or even multimedia content.

\section{Method}

\section{Focus of the study}

The mindset of an era, the attitudes and values of society, in some forms are reflected in the content released by the press, i. e. in the media. Examining these can thus be useful for exploring professional and lay public positive and negative opinions concerning glass façades. 
The present study focuses introducing the Grounded Theory method via the example of comparing the opinions conveyed via three different sources about glass-buildings. Therefore three different methods were used to collect data. First, respondents were asked about their opinion, second and third lay and architecture oriented journals were questioned regarding their content about glass-buildings. This study is an exploratory, qualitative content analysis.

Grounded Theory was used for data analysis (Glaser-Strauss 1967; Corbin-Strauss 2015), which is a suitable method for developing new theories and category systems in a field that has not been systematically studied (Pace 2004), such as opinions about glass façades. Thanks to this method both manifest and latent content could be analyized (Babbie 2015). Sometimes cynical tones appear in the articles, so the analysis of manifest content might be misleading, and therefore it is particularly important to examine the latent content (Keszei 2012).

\section{Method1 - Analyzing laymen's opinions}

The first part of the research focused on examining the opinion of people about glass façade buildings. Participants were shown pictures of buildings having different 'amount of glass' on their façades and were asked to write down the first five words or expressions that came to their minds. General demographic data was also collected (Keszei 2008).

\section{SAMPLING}

The only sampling criterium was the age of the participants who for ethical reasons had to be mentally healthy adults (18 years old or above). Convenient sampling was used. The questionnaire was mostly distributed via email, but paper-pencil versions were also used during data collection (Keszei 2008).

\section{STIMUli}

Two types of stimuli were used: images of already completed, existing buildings and architectural visualizations. During the process of selection of stimuli a few guidelines were used: excluding extreme, purposefully 'iconic' designs; buildings having roughly similar function (e. g. office building, shopping malls, cultural centers); having different amounts of glass surface among the buildings (Keszei 2008).

For the photorealistic architectural visualizations stimuli the images of the buildings were selected from an architect's practice, therefore the buildings werescheduled to be 
built within a few years. For the pictures of existing buildings we took pictures of the glass buildings in Budapest (Keszei 2008).

A common problem when examining physical environments is how to delimit the researched area, how large an area the research is focusing on. This question also appears in field research and in research using photographs or other visual stimuli. In the latter case, we can easily control how much the building can be seen from the surrounding space on the stimulus. With the 'narrow' environment, we can separetathe building from its environment, thereby significantly changing the connotation of the building and reducing the ecological validity of the study. During the process of choosing stimuli, our principle was to emulate the user's point of view (maintaining the eyelevel and a constant distance from buildings).

\section{Figure1: Stimuli of the 6 buildings used in the first phase of the research (Keszei 2008)}
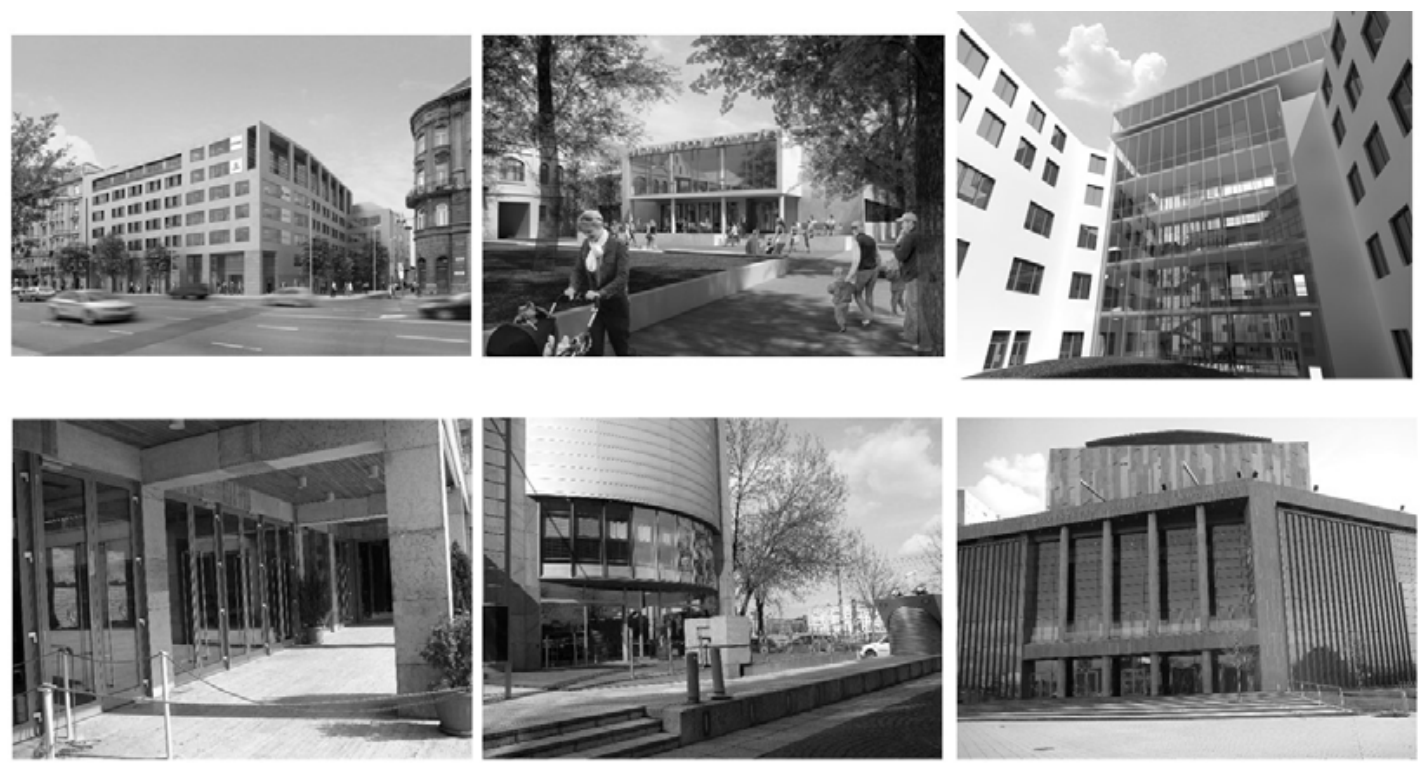

The final selection was made with the help of 5 professionals, who helped us adapt the guidelines to create the right balance regarding the stimuli being diverse enough while still meeting the requirements toward the stimuli. The first selection process resulted in 24 pictures (existing buildings and architectural visualizations, 3 levels of 'amount of glass on the façade', daytime and night versions, looking from the inside out, and vice versa). The pilot study showed that the amount of pictures and the related questions can not be answered in a reasonable amount of time, therefore a smaller selection of the stimuli was used in the actual research. The final stimuli contained only daytime 
pictures, taken only from outside of the buildings. The 3 levels of 'amount of glass on the façade' variable could be kept. Therefore 3 pictures of real buildings and 3 pictures of architectural visualizations were used (see Figure 1) (Keszei 2008).

\section{Method2 - Analyzing opininons expressed in professional journals}

In the second and third phase of the research architectural and lay journals were studied to collect the published opinions about glass façade buildings in this segment of the media (Keszei 2012).

Another possible option would have been to use the sampling based on the authors of the articles dealing with glass façade buildings. These authors usually publish both in lay- and professional journals, however there is a conspicuous tendency to be notedthat while in the cultural publicity journals (e. g. Debrecen Dispute) authors mostly write for critical-analytical purposes, in the other journals works of the authors from other art or science fields are more frequent (Bun 2006). Writers of the articles can represent a special architectural school, a point of view, with its specific aesthetic judgments and category systems. In the present study the method of choosing the articles by the author was excluded because our research aimed to show the widest possible range of opinions about glass façade buildings (Keszei 2012).

\section{SAMPLING}

The first step of sampling was to determine the researched era based on content published in professional media outlets. Although glass façades, or at least extended glass surfaces (glass walls, glass doors) were present since the 1920's and architectural modern was strongly tied to Hungarian architects (e. g. Farkas Molnár, László MoholyNagy) (Bonta 1995; Mertins 2011), only a few publications were found in the most prevalent architectural journal Space and Form (Tér és Forma) between its release in 1926 and 1945. Only a few exceptions were found, being mostly glass portals, some industrial buildings and some villas. The following periods did not favor glass buildings. World War II, the Hungarian Revolution of 1956 and the building of mostly blockhouses during the socialist regime did not allow for the appearance of 'western-looking' glass curtain walls. There were only a few exceptions to this trend: the Hotel Duna Intercontinental, designed by József Finta (opened in 1969), the International Trade Center (1985) and the Hilton Hotel (1976). After 1989, however, curtain wall construction began, e. g. Kempinski Hotel Corvinus (1992), Bankcenter (1995), Police Headquarters (1997), and Westend City Center, (2000). Therefore the research concentrated 
on the buildings and their appeareance in the media from after the regime change in Hungary (Keszei 2012).

The next step of sampling was to choose the buildings, façades that can be potential candidates for being in the final pool of stimuli. The criteria for being considered as a stimuli was to be a glass-façade building and being written about in multiple media outlets, preferably more than one media outlet in both the lay- and in professional category (Keszei 2012).

From all the possible media coverage of glass buildings the research focused on print media, print journals and magazines. In the selection of professional media outlets the work of Kerékgyártó and Simon (2006), Kerékgyártó (2006); served as a guideline to find the relevant sources in the myriad of journals.

When choosing the professional journals, Floor Plan (Alaprajz), Atrium, Octogon, Country Builder (Országépítő) and Old-New Hungarian Architecture (Régi-új Magyar Építőművészet) stood out. The journals focusing on construction and building engineering were excluded from the study. Country Builder also had to be excluded because it concentrates on organic architecture, therefore there is not much glass appearing on the buildings shown in the journal (Keszei 2012).

\section{Method3 - Analyzing opininons expressed in professional journals}

\section{SAMPLING}

Regarding lay journals Bun's (2006) work outlines the direction of outlets publishing articles related to architecture. Bun found 39 Hungarian journals in which architecture was pictured as a public domain, as an identity-forming terrain, as a means of power, as art, as an environment-forming force. $62 \%$ of public magazines do not show any architectural content at all. The literature-based Hungarian public thinking is also aptly characterized by the fact that 17 of the 39 examined journals belonged to the literary, social science category, none of which included any architecture. Bun found that the following journals in the displayed categories contained articles related to architecture and buildings (Bun 2006).

- Cultural Public journals: Budapest, Echo, Cityscape (Városképek), Debrecen Dispute (Debreceni Disputa)

- General Public journals: Life and Literature (Élet és Irodalom), Millennium (Ezredvég), Critique (Kritika), Hungarian Orange (Magyar Narancs), Past and Future (Múlt és Jövő), Expert (Müértő), Reality (Valóság) 
- Cultural and local history journals: Budapest Quarter (Budapesti Negyed), Pecs Review (Pécsi Szemle)

- Fine Art journals: Balkon, New Art (Új Müvészet)

From the above mentioned journals the articles that mentioned the use of glass on façades were included in the sample. However, the sample of articles collected by searching with keywords proved to be narrow even using the broad category of glass façade. Thus the topic needed a different approach, namely using the names of buildings with glass façades (Keszei 2012).

Buildings in public journals were either with public or cultural function. Most often, the Holocaust Museum (Holokauszt Múzeum) in Páva Street, the Palace of Arts (Müvészetek Palotája), the Kálvin Center, the National Theater, the ING Headquarters in Dózsa György Street, the Lehel Markethall and the Budapest Sportarena appeared in the journals. (Bun 2006) Four of these buildings have glass façades, but more buildings needed to be selected for the purposes of the study. In a pilot study 10 people from different age groups (21-74 years) were asked to name glass façade buildings built after the regime change in Hungary in 1989 (Keszei 2012).

The following buildings were finally included in the study in method 2 and 3 as a good deal of professional and public articles were found on these: Whale (Bálna), University of Debrecen Life Sciences Center and Library (Debreceni Egyetem Élettudományi Központ és Könyvtár), Debrecen Grand Market (Debreceni Nagypiac), Kalvin Center and Tower (Kálvin Center és Tower), Chain Bridge 19 Design Hotel (Lánchíd 19 Design Hotel), City Center Millennium (Millenniumi városközpont), Media Service Support and Asset Management Fund Headquarters (MTV Székház), Palace of Arts (Művészetek Palotája), Stefánia Park Office Building, Vörösmarty 1. To enlage the sample the keyword 'glass' was also used to find more related articles in the above mentioned lay- and professional journals. For the detailed methods of choosing the glass façade buildings and the list of the analysed articles see Keszei (2012).

\section{Results}

The occurring categories of the opinions on glass façades in lay-and professional journals

The elaborate introduction of our results aims to serve as an example as to how detailed an explanation is needed to present the findings, occurring categories of a qualitative 
content analysis using the Grounded Theory method. Naturally the particular topics and research questions also have an impact on how detailed these results will be.

In our research a total of 1983 answers were colllected from the questionnaires described in Method1. As a first step of data reduction, similar answers were classified into the same category, if needed the parts of speech were changed to fit into the categories which were adjectives (e. g. naturalness - natural). At this stage, the goal was to put as many answers into categories as possible, leaving the fewest answers that occurred only once. As a result 250 categories were created (Keszei 2008).

In the next step Q-sorting was used. Based on the sorting and using grounded theory with the help of three people the following main categories were defined: mass effect, physical characteristics, evaluation of the building, design quality, affections, connection to the environment, and finally the words that mark the specific building (Keszei 2008).

Table 1 presents the main categories and the related positive, negative and neutral categories. The number of adjectives related to the given category is shown in brackets. Of course, an overlap between content categories is possible (e. g. the 'cube' category, which is classified within mass effect, is also included in the 'cube' category of the physical characteristics). This category system serves the purpose of this study and tells a lot about the meaning and the connotations of buildings with glass façades (Keszei 2008).

In the opinion of lay people a dominant judgment can often be seen between opposing meanings. One of the exceptions is the friendly-unfriendly pair of adjectives, which has almost the same prevalence on both the positive and the negative sides. There is a possibility of getting misleading results due to the peculiarities of the stimuli. Since some images had people on them and some did not, this difference may have influenced the evaluation of the environments. For example it is harder to characterize the environment as 'empty' when people walking by are depicted on the picture, while it might be easy to find an environment friendly if children are playing on the picture. In the stimuli used there is only one image on which there are clearly visible human figures, therefore their effect could not have a prevalent effect on the pattern of opinions discovered during the content analysis (Keszei 2008).

Based on the category of 'affections' developed in content analysis, an unfriendly but somewhat cheerful image revealed itself through the analysis. In the 'evaluations of the building' category, the distribution of positive and negative opinions is more balancedwith a large number of neutral attributes. However, in some cases the negative connotation is dominant: the category 'boring' appears three times as often as 'interesting', and 'stiff' five times more than 'pleasant'. The two most dominant categories are 'stiff' and 
'simple'. The expression 'simple' carries both the positive connotations of clarity and also the negative content of being chaotic and boring (Keszei 2008).

Table 1: The category system based on lay people's opininons about glass façades (Keszei 2008)

\begin{tabular}{|c|c|c|c|}
\hline Main category & Positive & Negative & Neutral \\
\hline Mass effect (347) & Spacious (44) & $\begin{array}{l}\text { Labile (4) } \\
\text { Empty (9) } \\
\text { Enclosed (31) }\end{array}$ & $\begin{array}{l}\text { Transparent (48) } \\
\text { Lack of transparency (15) } \\
\text { Cube (21) } \\
\text { Enormous (117) } \\
\text { Distributed (11) } \\
\text { Compact (50) }\end{array}$ \\
\hline $\begin{array}{l}\text { Physical } \\
\text { characteristics (214) }\end{array}$ & Light (54) & $\begin{array}{l}\text { Grey (64) } \\
\text { Noisy (10) }\end{array}$ & $\begin{array}{l}\text { Curved (9) } \\
\text { Stony (5) } \\
\text { Colorful (9) } \\
\text { Angular (39) } \\
\text { Reflecting (24) }\end{array}$ \\
\hline $\begin{array}{l}\text { Evaluation } \\
\text { of the building (760) }\end{array}$ & $\begin{array}{l}\text { Safe (7) } \\
\text { Dinamic (22) } \\
\text { Elegant (89) } \\
\text { Interesting (28) } \\
\text { Inviting (26) } \\
\text { Pleasant (42) }\end{array}$ & $\begin{array}{l}\text { Ugly (65) } \\
\text { Chaotic (17) } \\
\text { Stiff (35) } \\
\text { Rigid (151) } \\
\text { Boring (86) }\end{array}$ & $\begin{array}{l}\text { Simple (143) } \\
\text { Striking (27) } \\
\text { Opened (32) }\end{array}$ \\
\hline Design quality (266) & $\begin{array}{l}\text { Artistic (27) } \\
\text { Precise (25) }\end{array}$ & $\begin{array}{l}\text { Temporary (5) } \\
\text { Impossible to use } \\
(11) \\
\text { Without a style (20) }\end{array}$ & $\begin{array}{l}\text { Functional (20) } \\
\text { Modern (14) } \\
\text { Social-realist (12) }\end{array}$ \\
\hline Affections (207) & $\begin{array}{l}\text { Friendly (44) } \\
\text { Jolly (10) }\end{array}$ & $\begin{array}{l}\text { Unfriendly (36) } \\
\text { Controlling (5) } \\
\text { Alien (7) } \\
\text { Depressing (26) } \\
\text { Disgusting (9) }\end{array}$ & $\begin{array}{l}\text { Subdued (16) } \\
\text { Official (54) }\end{array}$ \\
\hline $\begin{array}{l}\text { Connection to the } \\
\text { environment (52) }\end{array}$ & $\begin{array}{l}\text { Fitting (4) } \\
\text { Natural (11) }\end{array}$ & Not fitting (22) & $\begin{array}{l}\text { Salient (7) } \\
\text { Urban (8) }\end{array}$ \\
\hline Specific building (68) & $\begin{array}{l}\text { My house is my } \\
\text { castle (7) }\end{array}$ & $\begin{array}{l}\text { Phalanster (4) } \\
\text { Market interest (11) }\end{array}$ & $\begin{array}{l}\text { Corridor (5) } \\
\text { 'function of the building' (41) }\end{array}$ \\
\hline
\end{tabular}


Within the 'design quality' category, the expression 'modern' appears often with both positive and negative overtones. The overtone could be inferred from the other answers of the participant at the given picture. In many cases, the expression 'socreal' appeared, which in the common Hungfarian lingo covers everything that reminds people of block houses. The distribution of the positive and negative adjectives regarding style and functionality is balanced (Keszei 2008).

The main category 'connection to the environment' can be considered the continuation of the previous one, since in this case design decisions are also judged to some extent. In most cases, however, the negative side of being salient was captured by the respondents. The meaning of 'natural environment' was probably positive, but on the opposite side, on urban environments no negative evaluation was found (Keszei 2008).

In addition to the former two categories, the emergence of 'mass effect' as a separate category may mean that there could very well be a connection between designers and users. In this study lay people were the respondents without any specific architectural knowledge and even they used some expressions related to the 'architects' point of view' (e. g. fit into the environment, talking about proportions), despite some heated notes, such as 'this building should be demolished'. Elements in the mass effect category are well separated from other categories. Most of the adjectives used, just like in the category of physical caracteristics, are neutral, or with opposite meanings (e. g. distributed - compact, spacious - closed, transparent - lack of transparency, colorful - gray, curved - angular). As expected, the properties of glass (transparent, reflective) appeared in the adjectives. Of course, in the case of such descriptive adjectives, the shape of the given building is decisive, the frequency do not provide much information about the global perception of glass façades. This is especially true for the category 'specific building' in which most of the function attributed to the building in question was named (Keszei 2008).

The collected data can be interpreted in many other ways. During the formation of the categories and the classifications it was one of our goals to make a helpful tool to know more about the aspects that can make an environment more pleasant for its users. It is worth mentioning that in evaluating an environment the quality of past experience with the given environment plays a major role that in individual cases can not be overlooked (Keszei 2008). 


\section{Results from the media analysis}

LAY AND PROFESSIONAL JOURNALS IN THE LIGHT OF THE STYLE OF THE ARTICLES

In the study we present the picture that emerged from comparing lay- and professional journals on the terms and professional expressions they used. Although the sample size did not allow for thoroughly examining the potential differences between the categories used by lay people and professionals, based on the sources examined, a prevalent difference could not be found between lay and professional papers. This result might be due to the fact that writers who publish in lay journals are all professionals in the field of architecture. However, there could have been a difference between the articles in professional and lay journals, as the authors could consider the potential differences in the target audience and adapt their terminology and style. It would be worth examining whether readers of professional and lay journals are satisfied with the articles, that is, they feel that the author is using the right categories, and that they encounter texts that are understandable to them. As for the authors, it is interesting to note that interviews with architects have often appeared in both lay- and professional journals. In these articles the architects, as professionals, expressed their opininons. The problem of category use encountered by authors in professional and lay journals is present also in the case of the interviewees. After all, architects are aware of what they might expect from such an interview. The question is whether the category differences between lay people and professionals are really significant, or whether they appear only in research arrangements that specifically call for and provoke different categories in different groups (Keszei 2012).

Regarding glass façade buildings a relatively homogeneous opinion was shown to have formed in the examined media content. Although opposing opinions appeared, there were only a limited number of critical approaches. With the exception of the Floor Plan, which expressed its professionalism compared to all other publications, there is a kind of homogeneity in the style of the journals as well. Of course, there are authors whose unique style is decisive, but the articles are similar and they convey similar opininons. This may be due to the fact that there are fewer and fewer journals that regard a wider public as their consumers. The previously opposing opinions had come closer and became uniform. However, there may be a distance between the public and the press. (Keszei 2012) With the proliferation of web portals and blogging, individual voices appear more in the public in general and specifically in the field of architecture as well. As an example I would like to name Wesselényi-Garay Andor, the author of 
WérGida, who is a remarkable and celebrated figure in the Hungarian architectural blogging (Martinkó 2009).

The obstacle of communication and harmonious interaction between lay people and professionals can also be a negative opinion of each other, and these can even be self-fulfilling prophecies (Smith-Mackie 2004). However, the negative perception of lay people did not only occur in the professional press. Labeling laymen as 'visual illiterates' appeared in a magazine while protecting the Kálvin Center (in Octogon by Béla Bordvendég). In a finer style, Magyar Narancs also criticized the 'city people' for their desire for nostalgic forms. Regarding the University and Library of Debrecen, Nóra Somlyódi writes: It would be nice to know when the public will be set free from the idea that a house can not be beautiful if it has a flat rooftop. Architects are presented in some lay journals (in Budapest Quarter by Noémi Saly, in Expert by Ildikó Lévai-Kanyó) as smug, stubborn, irresponsible people who do not care about their environment, who are guilty of visual pollution, and who are highly motivated by the market's needs (Keszei 2012). We have to add that the usage of flamboyant and heated expressions and opininons in the media might be the very reason why consumers read these articles.

\section{CATEGORIES OF OPINIONS ON GLASS FAÇADES OCCURING IN LAY AND}

\section{PROFESSIONAL JOURNALS}

In this section, the opininons related to glass façade buildings expressed in lay-and professional journals are shown according to the categories emerging via using the Grounded Theory method. It's worth noting that in many cases, although glass façades were mentioned in the article, no more attention was paid to it. This is particularly interesting in examples where glass dominates the façade or it actually is a dominant element of the building (Keszei 2012).

\section{Reflection}

In the case of reflective surfaces, opinions were first and foremost positive. Reflecting and re-viewing the surrounding buildings is among the greatest virtues of glass. In addition, reflection as a tool to fit into the environment, as a humble alignment appears among the interpretations. (Keszei 2012).

Variety was a frequently encountered topic related to reflection. The urban image that appears on the reflective surfaces, appeared in the articles both with positive and negative overtones. The ambivalent perception of the reflective properties of glass surfaces may be due to the need for extra attention to understand these surfaces. Until we 
fully understand what we are seeing, it can maintain our interests. Certain glass façades are subject to change in different weather conditions, and this variation is greater than with traditional buildings and can also be perceived as disturbing. (Keszei 2012) However, perhaps this can be counterbalanced by the fact that this feature is constant, and as iconic or imaginable elements of the city (Lynch 1960) these buildings can serve as a point of reference, which in turn can provide a sense of security in urban orientation (Keszei 2012.) It is important to note that an environment does not delight us with its stability but with its variability (e. g. changes in the complexity of our environment) (Rapoport 1977).

The expression 'shimmer' appeared frequently along with reflection. However, this 'shimmer' or 'sparkle' was ambivalent: it was sometimes associated with high-tech as a negative 'metallic fancy-schmancy', or as a positive element in 'opening the contours of the scarce space' (Keszei 2012).

\section{Light}

Light appeared as a separate category from reflection and the upcoming 'insight' and 'high.tech' categories. An article about Köbánya Cinema describes best the essence of the category: 'This cinema comes to life from the lights.' (Keszei 2012).

\section{Insight}

The category 'insight' was a relatively rare one and it was related to transparency. Just like in the case of the Reichstag, it symbolizes its transparency, the purity and accessibility of the processes within the building. Transparency itself had a negative connotation in nonspecific cases: 'It is a myth that glass is invisible because it is translucent (it is an effect only appreciated from the inside); this strange roof [referring to the specific shape of the building's roof] will be present in the outer space as a large, temporary foil tent' (Keszei 2012).

'Insight' in one case appeared as a negative term regarding the University of Debrecen and the Library, where the view was considered a distraction. Apart from this one exception, the category 'insight' was without exception presented with a positive tone. This category included openness, lightness, youthfulness and even the term 'lightweight structure' (Keszei 2012). 


\section{Blurring of in and out}

The separation from the insight categories is justified because a lot of the articles used expressions like 'boundaries disappearing, dissolving or blurring'; 'involving external life', 'membrane' and 'glass membrane'. This blur has often been associated with the idea of blurring natural and artificial boundaries. For example in the church architecture of the 20th century this message is carried by glass as a building material. Even though our study dealt exclusively with secular architecture, the term 'miracle' appeared as an item in the category (Keszei 2012).

'Blur in' and 'blur out' as categories often appeared in houses that were built in or near natural landscapes. In this context, it is important to compare the various layers the term natural has in its meanings, because it may well be that architects and laymen understand it differently. Architects use the word 'natural' often as a synonym for sincerity (e. g. Vörösmarty 1 by Magyar Narancs, Millenium Tower III and Kálvin Center in Octogon). For them, a building is natural if its shape, material usage and other architectural solutions match the space's features, function and aesthetics. In contrast, for lay people, natural means that the building is placed in a natural environment as opposed to an urban, dense environment (Keszei 2012).

\section{Relationship with the environment}

One of the most frequent critical aspects encountered when examining lay articles was the relationship with the environment. Glass surfaces have not played a central role in this, but their significance regarding this issue is not negligible. The positive role of glass surfaces in the cityscape receieved a positive media coverage when it was related to reflection. But in other cases, when reflection was not mentioned, glass façades were always accompanied by negative criticism. In these articles glass buildings appear as a villain of sorts, as the 'destroyer of historic cityscape', as an alien not having any relationship with its surroundings (Keszei 2012).

The proportions of the building certainly play a significant role in judging the environment. These proportions are either the volume of the building or the use of materials, which together determine the spatial experience. When this ratio was optimal, the building was portrayed as 'well-composed music' (Keszei 2012).

Through the broader interpretation of the category we reach beyond the physical fit of the building and dive into the socio-political-economic fit. The following topics were most frequently mentioned related to the political environment: tenders, the process 
of the tender, restricted tendering, the thoughtfulness of the tender, etc. (Keszei 2012). Though these topics spell out the broader political context of the building, they are still quite professional, as some knowledge about the tenders would be required to correctly assess the buildings themselves and that is hardly ever the case when it comes to lay people.

In professional journals the architectural idea or the lack of it in a review are much more frequent than in lay journals. This is the case even though these journals are supposed to introduce lay readers to the process of creation, to help them better understand what is happening in our environment. However, it is true that buildings communicate without background stories. These are the messages that are accessible to everyone as they see and experience a building. An ill-conceived building can diverge from 'the original idea, but since architecture has always depended on power (Sudjic 2006), it is necessary to learn to work together to create the best buildings. In this collaboration, it is important to know that laymen (and, from an architectural point of view, this group often includes the investors themselves) and architects understand each other. They should know how the other thinks about values, how they understand form language and its connotations.

\section{High-tech}

The context of a building can be defined - among others - by its style. This is indicated by mentioning high-tech and the obsolete postmodern style. In addition to high-tech, sophisticated and precious often appeared in the articles, sometimes even associated these terms with being iconic. In this context, the 'glass-steel cube' appeared as a symbol of power.

However, even more pronounced was another interpretation of the aforementioned 'glass-steel cube' or 'glass box', according to which such buildings are uniform, boring and altogether not special. Fear of being conventional appeared in the articles about Stefánia Park and the University and Library of Debrecen. In both of these cases the authors acknowledged with great relief that glass buildings had not become 'one-ofthe-many'.

In the case of high-tech and postmodern, glass is mentioned together with steel and 'noble stone', but also linked to negatively evaluated mall architecture. Often, iconic architecture is mentioned in connection with glass façades. The perception of iconic architecture and buildings is mixed. In addition to the degrading 'fashion page architecture', playful and statuesque expressions appear with positive overtones. Glass can 
be a popular material in iconic architecture as it allows a variety of forms to be molded into, and the play of light and shadow make it easy to amuse its users (Keszei 2012).

\section{THE COMPARISON OF INDIVIDUAL OPINIONS AND MEDIA COVERAGE ON GLASS} FAÇADES

As we already mentioned above, it is important how researchers choose their samples when examining opinions. The Grounded Theory analysis run on three different sources has been shown above: Lay media, professional media and laymen's opinions (without the potential modifying effect of being in a media setting). Now we compare differences between the categories and opinions emerging from these different sources. We focus on presenting disparities in the frameworks.

When comparing opinions about any given topic of individual respondents and media outlets, we find ourselves in a chicken and egg situation when trying to figure out which opininon influenced the other. Although the purpose of the study was merely to explore these opininons, the question immediately arises: how can these opinions be moderated, changes or affected?

The respondents - presumably - read journals or at least live in the same culture that produced these journals, therefore the media must have some kind of effect that is reflected in the opinions of individuals. On the other hand media outlets have to sell their products, therefore they need to provide goods that consumers like and will want to consume again. Hence familiar opinions should be spread on the pages of lay and professional journals, magazines.

As we have seen above in the field of positive/negative overall evaluation of glass façades, not much difference could be detected in the opinions represented in lay- and professional journals. Although 'reflection' was a common category in the media converage, individuals were more often using the expression 'light', not at all, or not much related to the content of the category 'light' as seen in the media.

The most prevalent variation was in the context lay and professional journals embedded the review of a given building. While professional journals used the framework of architectural theory and sometimes the practicalities of engineering, lay journals focused more on the political and socio-economic context of the building.

'Fit for the environment' in lay journals refers to whether the shape fits its environment, whereas while in professional journals this aspect does appear, the architectural 'hidden message' is much more articulated. The aspect of 'fitting' is appreciated along these ideas. Of course, it is possible that a building, although for various reasons, receives positive criticism from the media (both lay and professional) and individuals 
too. As obvious, the opposite can also happen, and sometimes even professionals disagree about whether the architectural idea was appropriate or not, whether the building has succeeded in achieving it or not. Because of the different data collection methods, certain aspects of the connotations can not be as elaborately discussed and interpreted in the case of individual respondents as in the articles. When we only have a maximum length of only a few words, latent meanings can not be communicated as deeply as in the case of articles spanning several pages.

In a few words it is difficult to write down a personal story, personal details related to the building, but published articles should seize the opportunity of sharing personal stories, making it even more relatable and potentially sellable.

The differences in the individual opinions and the ones conveyed by the media is that more heated, sometimes even aggressive opinions appeared in individuals than in print media. Although it has to be noted that even in journals quite sarcastic or rude descriptions happened to be published. There might be very different reasons for giving negative or even rude desripitions and evaluations to glass façade buildings. In an anonymous questionnarie it might seem easy to give an honest, probably aggressive reaction to a building, but in the media the attention of the reader needs to be captured, therefore fierce, sarcastic articles might fulfill these needs of readers.

\section{SELF-CRITICISM}

The Grounded Theory method has been a brilliant tool to explore the meanings and interpretations of glass façades. Although regarding the terminology, researchers have to be very careful, because while at the beginning of the research certain professional expressions might seem far from the vocabulary of lay people, hours and hours of reading architectural text can change one's preception. A possible solution may be to work in a research group and start to read the sample texts from different starting points. This way the same text will be seen with a fresh eye at least by one researcher, and the effect of getting used to certain expressions within the examined text can also be lessened.

A common problem with the gounded theory method is that it refuses using previous knowledge of preesxisting schema or preconception about the researched topic. This criterium is hard to satisfy when a researcher is already working within the field. In our case our previous knowledge about modern architecture was hard to ignore when creating a category system based on our data. Obeying one of the rules of Grounded Theory, to reread the text multiple times, is essential in these cases. A text should be 
almost learned by heart by the rearchers, and when accumulating a virtually insider relationship with the text, the effect of our preconceptions diminish.

As the next step of the research in order to explore a wider range of professional and lay opinions, an analysis should be conducted about architect blogs and comments (Kerékgyártó 2006; Turai 2006).

\section{Conclusion}

The present study demonstrated the application of the Grounded Theory method and its usefulness in analyzing differing opinions. We used the evalutation of glass façade buildings as an example to present the different sampling methods and their challenges in accumulating and comparing data from different sources. Although using multiple sources would help to have a better approach on the given topic, triangulation (Biggerstaff 2012) has its own difficulties. Choosing the proper stimuli and sample is always a demanding task, and questionable decisions will always be made. Still, researchers has to balance the advantages and disadvantags of each decision in the given research, related to the research questions. Research in environmental psychology always struggles with the dilemma of where to draw the boundaries of the researched area. In the current study the focus was on glass façades but that can not be separated form the building itself, form its environment in its broad physical, political, historical, social etc. sense. These layers - as well as the personal experience of the respondent- have an effect on the evaluation. In this sense it does not matter if the respondents are responsible only for their own opininons or as publishing authors they have to consider the potential impact they might have on society. The question of self-censorship arises as well as the interest of the media outlet the author is working for.

\section{References}

Babbie, E. R. (2015): The practice of social research. Nelson Education.

Bataille, G. (1929): Architecture. In Leach, N. (ed.): (1997): Rethinking Arcitecture: A Reader in Cultural Theory. London: Routledge, 21.

Batár A. (2005): Láthatatlan épitészet. Ab Ovo Kiadó.

Biggerstaff, D. (2012): Qualitative Research methods in psychology. In Rossi, G. (ed.): Psychology-selected Papers. InTech, 175-206. Available at: http://www.intechopen. com/books/psychology-selected-papers/qualitative-research-methods-in-psychology (2018. 11. 10.). 
Bonta J. (1995): Modern épitészet - posztmodern épitészet. Budapest: Müegyetemi Kiadó.

Brózik P. (2006): Épített környezet és személyes konstruktumok. Magyar Pszichológiai Szemle, (61)1, 67-86.

Brown, G. - Gifford, R. (2001): Architects predict lay evaluations of large contemporary buildings: Whose conceptual properties? Journal of Environmental Psychology, 21, 93-99.

Bun Z. (2006): Építészet a kulturális sajtóban, a könyvkiadásban és a nem írott médiában. Utóirat, 4, 14-26.

Carleton, R. N. (2016): Into the unknown: A review and synthesis of contemporary models involving uncertainty. Journal of Anxiety Disorders, 39, 30-43. doi: 10.1016/j. janxdis.2016.02.007.

Corbin, J. - Strauss, A. (2015): A kvalitatív kutatás alapjai. A Grounded Theory elemzési módszer technikája és eljárásai. L'Harmattan-Semmelweis Egyetem EKK MHI SAGE Publications.

Crinson, M. (2012): Glass architecture: A riotous mythology. Available at: http://www. metamute.org/editorial/articles/glass-architecture-\%E2\%80\%93-riotous-mythology (2012. 4. 3.).

Cseri L. (1998): A szürkületben meghalnak a házak: Fotográfia és építészet. Echo, okt. 4. Dasgupta, N. - DeSteno, D. - Williams, L. A. - Hunsinger, M. (2009): Fanning the flames of prejudice: The influence of specific incidental emotions on implicit prejudice. Emotion, (9)4, 585. https://doi.org/10.1037/a0015961.

Deriu, D. (2001): Opaque and transparent. Writings on urban representations and imgainations. Journal of Urban History, (27)6, 794-803.

Donald, J. (1999): Imagining the Modern City. London: Ahlone.

Dúll A. (2017): Épített környezet és pszichológia. A lokalitásélmény környezetpszichológiai vizsgálatai. Akadémiai doktori értekezés. Budapest.

Dúll A. - Urbán R. (1997): Az épített környezet konnotatív jelentésének vizsgálata: módszertani megfontolások. Pszichológia, (17)2, 151-179.

Fawcett, W. - Ellingham, I. - Platt, S. (2008): Reconciling the architectural preferences of architects and the public: The ordered preference model. Environment and Behavior, 40, 599-618.

Gifford, R. - Hine, D. W. - Muller-Clemm, W. - Shaw, K. T. (2002): Why architects and laypersons judge buildings differently: Cognitive properties and physical bases. Journal of Architectural and Planning Research, (19)2, 131-148. 
Gjerde, M. (2011): Visual evaluation of urban streetscapes: How do public preferences reconcile with those held by experts? Urban Design International, 16, 153-161.

Glaser, B. G. - Strauss, A. L. (1967): The Discovery of Grounded Theory. Chicago: Aldine.

Gyáni G. (2005): A reprezentatív város - a reprezentált város. In N. Kovács T. - Böhm G. - Mester T. (szerk.): Terek és szövegek: Újabb perspektívák a városkutatásban. Budapest: Kijárat Kiadó, 229-237.

Hidayetoglu, M. L. - Yildirim, K. - Cagatay, K. (2010): The effects of training and spatial experience on the perception of the interior of buildings with a high level of complexity. Scientific Research and Essays, (5)5, 428-439.

Jarosinski, E. (2002): Architectural symbolism and the rhetoric of transparency: A Berlin ghost story. Journal of Urban History, 29, 62-77.

Kaplan, R. (1973): Predictors of enironmental prefeence: Designers and clients. In Preiser, W. F. E. (ed.): Environmental Design Research. Stroudsburg, PA: Dowden, Hutchinson Ross.

Kerékgyártó B. (2006): Az építészeti folyóiratok és a nyilvánosság. Az építészet megváltozott helyzete és az építészeti lapok. Utóirat, 4, 7-13.

Kerékgyártó B. - Simon M. (2006): Az építészeti nyilvánosság. Helyzetfelmérés tanulságokkal. Utóirat, 4, 4-6.

Keszei B. (2008): Az épített környezet olvashatósága: az üvegfelületet tartalmazó homlokzatok környezetpszichológiai vizsgálata. (Szakdolgozat) ELTE PPK.

Keszei B. (2012): Üvegfelületek megítélése a XX-XXI. században. (Szakdolgozat) BME GTK.

Kreps, D. M. - Milgrom, P. - Roberts, J. - Wilson, R. (1982): Rational cooperation in the finitely repeated prisoners' dilemma. Journal of Economic Theory, (27)2, 245-252.

Lynch, K. (1960): The Image of the City. Cambridge: MIT Press.

Martin, W. M. - Fruchter, R. - Cavallin, H. - Heylighen, A. (2007): Different by design. AI EDAM. Artificial intelligence for engineering design. Analysis and Manufacturing, (21)3, 219-225.

Martinkó J. (2009): Minek a mije? Élet és Irodalom, május 22., 30. o.

Nagy B. (2005): A település, az épített világ. In Farsang B. (2008): Igényre szabva. Philip Morris irodaépület. Octogon, (3)60, 61-62.

Pace, S. (2004): A grounded theory of the flow experiences of Web users. Journal of Human-Computer Studies, 60, 327-363.

Rapoport, A. (1977): Human Aspects of Urban Form. Oxford: Pergamon. 
Sántha K. (2009): Bevezetés a pedagógiai kutatás módszertanába. Budapest: Eötvös József Könyvkiadó.

Smith, E. R. - Mackie, D. M. (2004): Szociálpszichológia. Budapest: Osiris Kiadó.

Somogyi K. (2015): Másképpen közelítve. Képalkotás a kortárs építészetről. In Dúll A. - Varga K. (szerk.): Rábeszélötér. A szuggesztív kommunikáció környezetpszichológiája. Budapest: L'Harmattan, 403-418.

Szabolcs É. (2001): Kvalitatív kutatási metodológia a pedagógiában. Budapest: Műszaki Könyvkiadó.

Szépvölgyi V. (2007): Sztárinterjú - A demokrácia az agyakban él, semmi köze az üveghez - Beszélgetés Hans Stimmann-nal, Berlin főépítészével. Octogon, (7)4, 23-25.

Szokolszky Á. (2004): Kutatómunka a pszichológiában. Metodológia, módszerek, gyakorlat. Budapest: Osiris Kiadó.

Sudjic, D. (2006): The Edifice Complex. London: Penguin Books.

Turai Z. (2006): Az építészet nyilvánossága az interneten. Utóirat, 4, 27-47. 